慶應義塾大学学術情報リポジトリ

Keio Associated Repository of Academic resouces

\begin{tabular}{|c|c|}
\hline Title & $\begin{array}{l}\text { Presynaptic } \mathrm{M}_{1} \text { muscarinic receptor modulates spontaneous release of acetylcholine from rat } \\
\text { basal forebrain slices }\end{array}$ \\
\hline \multicolumn{2}{|l|}{ Sub Title } \\
\hline Author & $\begin{array}{l}\text { 鈴木, 岳之(Suzuki, Takeshi) } \\
\text { 藤本, 和子(Fujimoto, Kazuko) } \\
\text { 大畑，尚代(Ohata, Hisayo) } \\
\text { 川島, 紘一郎(Kawashima, Koichiro) }\end{array}$ \\
\hline Publisher & 共立薬科大学 \\
\hline Publication year & 1988 \\
\hline Jtitle & $\begin{array}{l}\text { 共立薬科大学研究年報 (The annual report of the Kyoritsu College of } \\
\text { Pharmacy). No.33 (1988. ) , p.155- } 155\end{array}$ \\
\hline \multicolumn{2}{|l|}{ JaLC DOI } \\
\hline \multicolumn{2}{|l|}{ Abstract } \\
\hline Notes & 抄録 \\
\hline Genre & Technical Report \\
\hline URL & $\begin{array}{l}\text { https://koara.lib.keio.ac.jp/xoonips/modules/xoonips/detail.php?koara_id=AN00062898-0000003 } \\
\text { 3-0155 }\end{array}$ \\
\hline
\end{tabular}

慶應義塾大学学術情報リポジトリ(KOARA)に掲載されているコンテンツの著作権は、それぞれの著作者、学会または出版社/発行者に帰属し、その権利は著作権法によって 保護されています。引用にあたっては、著作権法を遵守してご利用ください。

The copyrights of content available on the KeiO Associated Repository of Academic resources (KOARA) belong to the respective authors, academic societies, or publishers/issuers, and these rights are protected by the Japanese Copyright Act. When quoting the content, please follow the Japanese copyright act. 


\title{
Presynaptic $M_{1}$ muscarinic receptor modulates spontaneous release of acetylcholine from rat basal forebrain slices
}

\author{
Takeshi Suzuki, Kazuko Fujimoto, Hisayo Oohata, \\ and Koichiro Kawashima
}

鈴木岳之, 藤本和子, 大烟尚代, 川島紘一郎

Spontaneous release of acetylcholine ( $\mathrm{ACh}$ ) from rat basal forebrain slices in the presence of cholinesterase inhibitor was directly determined using a specific radioimmunoassay for $\mathrm{ACh}$. The release was calcium dependent. A consistent amount of $\mathrm{ACh}$ release was observed throughout the experiment. Atropine $\left(10^{-8}\right.$ to $\left.10^{-5} \mathrm{M}\right)$ and pirenzepine $\left(10^{-7}\right.$ to $\left.10^{-5} \mathrm{M}\right)$ enhanced spontaneous $\mathrm{ACh}$ release. These findings indicate the presence of an $M_{1}$ muscarinic autoreceptor that modulates spontaneous release of $\mathrm{ACh}$ in the rat basal forebrain.

* 本報告は Neuroscience Letters, 84, 209-212（1988）に発表. 